\section{An unusual case of airway rescue in the prone position with the ProSeal laryngeal mask airway}

To the Editor:

An obese 58-yr-old male was undergoing extensive lower back surgery in the prone position. His head was face down on a support ring and the tracheal tube was attached strongly with adhesive tape. Facemask ventilation in the supine position had been difficult and laryngoscope-guided tracheal intubation had been accomplished at the first attempt using a gum elastic bougie, as the patient had an unexpected high anterior larynx. Midway through the procedure ventilation became difficult due to a massive leak. A rapid inspection revealed that the tracheal tube had been displaced by approximately $5 \mathrm{~cm}$. On the assumption that the distal portion of the tracheal tube might still be aligned with or within the glottic inlet, the cuff was deflated and a single attempt made to push the tracheal tube back into position, but this resulted in esophageal intubation. While rapid preparations were made to rotate the patient back into the supine position for airway rescue and with the $\mathrm{SpO}_{2}$ still $>95 \%$, the gum elastic bougie was inserted with its straight end first along the esophageally placed tracheal tube, the tracheal tube was removed and a ProSeal laryngeal mask airway (ProSeal LMA; The Laryngeal Mask Company, Henley-on-Thames, UK) railroaded along its drain tube into position in the pharynx. The airway tube was immediately attached to the anesthesia breathing system and ventilation commenced with tidal volumes $>1000 \mathrm{~mL}$ at peak airway pressures of $25 \mathrm{~cm} \mathrm{H}_{2} \mathrm{O}$. The ProSeal LMA was then taped into position, the gum elastic bougie removed and a gastric tube inserted. The case was completed with the ProSeal LMA in situ. There were no other problems.

Joseph Brimacombe $\mathrm{MD}^{*}$

Christian Keller MD $\dagger$

James Cook University, Cairns Base Hospital, Cairns, Australia*

Medical University Innsbruck, Innsbruck, Austria†

E-mail: jbrimaco@bigpond.net.au

\section{Methylene blue in congenital met- hemoglobinemia: prophylactic or on demand?}

To the Editor:

We read with interest the article "Prophylactic methylene blue in a patient with congenital methemoglobinemia". ${ }^{1}$ However, we feel the patient's condition did not warrant prophylactic administration of methylene blue. Surgery of this patient was cancelled previously because of severe hypoxia due to respiratory depression following induction of anesthesia without preoxygenation. But oxygenation had improved following ventilation with $100 \%$ oxygen, before giving methylene blue. ${ }^{2}$ On this occasion however, the patient was preoxygenated following which, $\mathrm{PaO}_{2}$ increased from 81.3 to $543 \mathrm{mmHg}$ and $\mathrm{SaO}_{2}$ from 96.2 to $99.7 \%$. Preoxygenation itself provided an adequate margin of safety against hypoxia. Homozygotes and compound heterozygotes for cytochrome b5 reductase deficiency are cyanotic but asymptomatic even with methemoglobin levels up to $40 \%$, and have less risk of acute deterioration after exposure to exogenous methemoglobin inducing agents. ${ }^{3}$ Symptoms of oxygen deprivation appear only as methemoglobin levels rise above $30 \% .{ }^{4}$ Intravenous methylene blue is indicated only for emergency treatment of "toxic" methemoglobinemia ${ }^{3}$ and is known to cause serious adverse effects.

In our opinion, anesthetic management of congenital methemoglobinemia should target oxygenation rather than methemoglobin levels, and pharmacological intervention to decrease methemoglobin levels should be attempted only when increased methemoglobin leads to impaired oxygenation. We feel that the authors should have proceeded without prophylactic administration of methylene blue and should have administered the drug only if increased methemoglobin levels lead to desaturation. Also, the authors should have ruled out G6PD deficiency.

Recently, we managed a case of congenital methemoglobinemia with coexisting Osler-Weber-Rendu syndrome. Despite associated pulmonary arteriovenous malformations, anesthesia was successfully managed without using methylene blue. ${ }^{5}$

Deepak Sharma MD

Mihir Prakash Pandia MD

Parmod Kumar Bithal MD

All India Institute of Medical Sciences, New Delhi, India

E-mail: mihirpandia@yahoo.co.in 


\section{References}

1 Baraka AS, Ayoub CM, Yazbeck-Karam V, et al. Prophylactic methylene blue in a patient with congenital methemoglobinemia. Can J Anesth 2005; 52: 258-61.

2 Baraka AS, Ayoub CM, Kaddoum RN, Maalouli JM, Chehab IR, Hadi UM. Severe oxyhemoglobin desaturation during induction of anesthesia in a patient with congenital methemoglobinemia. Anesthesiology 2001; 95: 1296-7.

3 Prchal JT, Gregg XT. Red cell enzymopathies. In: Hoffman R, Benz EJ, Shattil SJ, et al. (Eds). Hematology Basic Principles and Practice. Philadelphia: Churchill Livingstone; 2000: 561-76.

4 Benz EJ Jr. Hemoglobin variants associated with hemolytic anemia, altered oxygen affinity, and methemoglobinemias. In: Hoffman R, Benz EJ, Shattil SJ, et al. (Eds). Hematology Basic Principles and Practice. Philadelphia: Churchill Livingstone; 2000: 554-61.

5 Sharma D, Pandia MP, Bithal PK. Anaesthetic management of Osler-Weber-Rendu syndrome with coexisting congenital methaemoglobinaemia. Acta Anaesthesiol Scand 2005 (in press).

\section{Reply:}

Thank you for referring the letter of Charma et al. concerning our report "Prophylactic methylene blue in a patient with congenital methemoglobinemia."

Our patient had severe congenital methemoglobinemia as evidenced by a methemoglobin level of 15.9\%. The case was scheduled on two previous occasions for turbinectomy, but was cancelled because of the development of severe hypoxemia during induction of anesthesia. ${ }^{1,2}$

On this occasion, the patient was preoxygenated prior to induction of anesthesia resulting in an increase of the $\mathrm{PaO}_{2}$ from 81.3 to $543 \mathrm{mmHg}$, associated with an increase of the functional oxygen saturation $\left(\mathrm{SaO}_{2}\right)$ $\left[\mathrm{O}_{2} \mathrm{Hb} / \mathrm{O}_{2} \mathrm{HB}+\mathrm{RHb} \times 100 \%\right]$ from $96.2 \%$ to $99.7 \%$. However, as shown in the Table, the fractional oxygen

TABLE Values of oxygen partial presure $\left(\mathrm{PaO}_{2}\right)$, saturation $\left(\mathrm{SaO}_{2}\right)$ and fractional saturation $\left(\mathrm{SfO}_{2}\right)$ and methemoglobin concentrations on room air, after preoxygenation, and after methylene blue administration

\begin{tabular}{|c|c|c|c|c|c|}
\hline & & $\begin{array}{l}\mathrm{PaO}_{2} \\
(m m \mathrm{Hg})\end{array}$ & $\mathrm{SaO}_{2}(\%)$ & $\mathrm{SfO}_{2}(\%)$ & $\begin{array}{l}\text { Methemoglobin } \\
\text { (\%) }\end{array}$ \\
\hline Room air & Room Air & 81.3 & 96.2 & 80.9 & 15.9 \\
\hline After preoxygenation & $100 \% \mathrm{O}_{2}$ & 543 & 99.7 & 84.1 & 15.8 \\
\hline $\begin{array}{l}\text { Five minutes after } \\
\text { methylene blue }\end{array}$ & $100 \% \mathrm{O}_{2}$ & 519 & 100 & 94.7 & 5 \\
\hline Second day & Room air & 86 & 96.9 & 93.4 & 2.6 \\
\hline
\end{tabular}

saturation $\left(\mathrm{SfO}_{2}\right) \mathrm{CO}_{2} \mathrm{Hb} / \mathrm{O}_{2} \mathrm{Hb}+\mathrm{RHb}+\mathrm{COHb}+$ $\mathrm{MetHb} \times 100 \%]$ which reflects the actual oxybemoglobin saturation, only increased from $80.9 \%$ to $84.1 \%$. Thus, preoxygenation alone did not provide an adequate margin of safety against hypoxemia. It was only after the administration of methylene blue that $\mathrm{SfO}_{2}$ increased up to $94.7 \%$, associated with a significant decrease of the methemoglobin level from $15.9 \%$ to $5 \%$.

The increase in $\mathrm{SfO}_{2}$ and the decrease in methemoglobin levels following prophylactic methylene blue were maintained postoperatively, which increased the safety margin against perioperative bypoxemia not only during induction of anesthesia, but also intraoperatively and during the postoperative period.

Anis S. Baraka MD FRCA

Chakib M. Ayoub MD

Vanda Yazbeck-Karam MD

Roland N. Kaddoum MD

Frederic J. Gerges MD

Ussama M. Hadi MD

Carla M. Dagher MD

American University of Beirut, Beirut, Lebanon

E-mail: abaraka@aub.edu.lb

References

1 Baraka AS, Ayoub CM, Yazbeck-Karam V, et al. Prophylactic methylene blue in a patient with congenital methemoglobinemia. Can J Anesth 2005; 52: 258-61.

2 Baraka AS, Ayoub CM, Kaddoum RN, Maalouli JM,Chehab IR, Hadi UM. Severe oxyhemoglobin desaturation during induction of anesthesia in a patient with congenital methemoglobinemia. Anesthesiology 2001; 95: 1296-7.

\section{Optimizing insertion of the ProSeal laryngeal mask airway}

To the Editor:

O'Connor et al. report an incidence of ProSeal laryngeal mask airway (PLMA) glottic insertion of $6 \% .{ }^{1}$

We should not conclude the PLMA increases the risk of glottic insertion. In the first classic LMA (cLMA) fibreoptic study 4\% of cLMA tips entered the glottis. ${ }^{2}$ Unlike the cLMA, the PLMA drain tube enables rapid diagnosis of misplacement.

During 656 elective adult PLMA insertions (age $52 \pm 17 \mathrm{yr}$, weight $76 \mathrm{~kg}$, range $34-140 \mathrm{~kg}$, > 90\% unparalyzed) my first time success is $83.2 \%$, overall success $99.8 \%$ and median seal pressure $33 \mathrm{~cm} \mathrm{H}_{2} \mathrm{O}$. 